\title{
Histone H2A Type 1-C
}

National Cancer Institute

\section{Source}

National Cancer Institute. Histone H2A Type 1-C. NCI Thesaurus. Code C162894.

Histone H2A type 1-C (130 aa, 14 kDa) is encoded by the human H2AC6 gene. This protein plays a role in the modulation of chromatin structure. 